\title{
AVAILABILITY FOR PLANTS OF PHOSPHORUS IN SOME VIRGIN PEAT SAMPLES
}

\author{
Armi KaIla \\ University of Helsinki, Department of Agricultural Chemistry
}

Received July 4, 1958

Most of the virgin peat soils in Finland are known to be poor in phosphorus. Even in newly reclaimed soils phosphate fertilizers are generally needed for the production of a satisfactory yield. Therefore, the subject of the present paper, availability to plants of the native peat phosphorus, probably only interests from the theoretical point of view.

It has been shown elsewhere that the largest part of peat phosphorus occurs in organic forms, at least in the more humified virgin peat (1). Since there is, at present, no reason to suppose that plants could, in noteworthy amounts, utilize these compounds before they are mineralized, only a fairly low quantity of inorganic phosphorus forms their direct source of this nutrient in peat soils. Also the inorganic phosphorus may often be difficultly available.

In the following results of an experiment are reported in which three successive crops of oats were grown in pots with peat as the only source of phosphorus. The phosphorus conditions and the solubility of inorganic phosphorus in the peat samples were studied by chemical methods. Also an incubation experiment was included in order to study the possibility of the mineralization of peat organic phosphorus.

\section{Material}

Eight samples originating from different kinds of virgin peat lands in Northern Finland were chosen for these studies. They were the following:

1. Sphagnum peat (Sp) from a Sphagnum pine bog with a virgin productivity (Bo) 1; The degree of humification according to von Post $\mathrm{H} 1$.

2. Carex-Sphagnum peat (CSp) from a Scirpus caespitosus-Sphagnum papillosum treeless bog, Bo 2, H 3.

3. Wood Carex-Sphagnum peat (LCSP) from an Eriophorum vaginatum-Carex pine bog, Bo 2-3, H 4.

4. Carex-Sphagnum peat (CSp) from a Carex rostrata bog, Bo $3, \mathrm{H} 4$. 
5. Sphagnum-Carex peat ( $\mathrm{SC}$ ) from a mesotrophic waterlogged treeless Carex bog Bo $6, \mathrm{H} 4$.

6. Wood Carex peat (LCp) from a wooded swamp with herbs and grasses, Bo 7, H 3-4.

7. Bryales-Carex peat $(\mathrm{BCp})$ from a Scorpidium fen, Bo 7, $\mathrm{H} 2-3$.

8. Eutrophic Sphagnum-Carex peat (EuSCp) from a birch fen, Bo 8, H 3.

All the samples were air-dried at room temperature and ground in a Wiley mill. They were analyzed for acidity, weight of volume, ash content and contents of extractable calcium, total phosphorus and organic phosphorus. Methods employed are explained in previous papers $(1,2)$. The data are reported in Table 1.

In spite of the fact that the first four samples were collected from peat lands of poor quality, and the other samples represent tillable peat lands, no marked difference between the characteristics of the samples in these two groups exists. Only the sample 1. Sp is distinctly more acid and the sample 8. EuSCp less acid than the other six samples. The volume weight of the sample 1. Sp is considerably lower than that of the other ones, and also the samples 7. BCp and 8. EuSCp deviate from the rest of the material in this respect. The lime content is fairly high only in the sample 8. EuSCp.

The amount of total phosphorus appears to vary markedly in these samples. There are samples 4 . CSp and 6. LCp with relatively high figures for phosphorus but the sample $7 . \mathrm{BCp}$ is considerably poorer in phosphorus than even the sample 1. Sp. Almost three quarters of phosphorus in the samples occur in organic form.

\section{Chemical analyses}

Phosphorus condition in the samples was first studied by some chemical methods. In addition to the determination of the total amount of inorganic phosphorus with successive acid and alkali treatments in connection with the estimation of organic phosphorus (3) also some less vigorous extractions were performed. A figure for the water-soluble phosphorus was obtained by three successive extractions with distilled water in the ratio of 1 to 20 , the shaking time was 5 minutes. Acid soluble

Table 1. Peat samples

\begin{tabular}{|c|c|c|c|c|c|c|c|c|}
\hline \multirow{2}{*}{ Sample } & \multirow{2}{*}{$\mathrm{pH}$} & \multirow{2}{*}{$\begin{array}{c}\text { Weight } \\
\text { of } \\
\text { volume }\end{array}$} & \multirow{2}{*}{$\begin{array}{c}\text { Ash } \\
\%\end{array}$} & \multirow{2}{*}{$\begin{array}{c}\text { Extract- } \\
\text { able Ca } \\
\text { ppm }\end{array}$} & \multirow{2}{*}{$\begin{array}{l}\text { Tot.P } \\
\text { ppm }\end{array}$} & \multicolumn{3}{|c|}{ Org. $\mathrm{P}$} \\
\hline & & & & & & ppm & $\%$ & of tot.P \\
\hline 1. Sp $\nrightarrow 1$ & 4.0 & 0.12 & 11.2 & 2000 & 500 & 360 & & 74 \\
\hline 2. $\mathrm{CSp} \mathrm{H}_{3}$ & 4.7 & 0.33 & 9.9 & 2800 & 660 & 530 & & 80 \\
\hline 3. LCSp $\mathrm{H}_{4}$ & 4.5 & 0.38 & 9.4 & 2600 & 980 & 790 & & 81 \\
\hline 4. $\mathrm{CSp} \mathrm{HY}^{4}$ & 4.5 & 0.34 & 12.4 & 1300 & 1080 & 900 & & 83 \\
\hline 5. $\mathrm{SC}_{\mathrm{p}}+{ }^{6}$ & 4.7 & 0.30 & 5.1 & 2700 & 820 & 570 & & 70 \\
\hline 6. LCp $H J-4$ & 4.9 & 0.36 & 6.7 & 6800 & 1120 & 800 & & 72 \\
\hline 7. $\mathrm{BC}_{\mathrm{p}}=2-3$ & 4.7 & 0.23 & 4.2 & 4300 & 370 & 270 & & 73 \\
\hline 8. $\operatorname{EuSC}_{p}=$ & 5.6 & 0.25 & 9.8 & 14000 & 640 & 500 & & 78 \\
\hline
\end{tabular}


Table 2. Inorganic phosphorus in peat samples

(Expressed as $\mathrm{mg} / \mathrm{l}$ of soil)

\begin{tabular}{|c|c|c|c|c|c|}
\hline \multirow{2}{*}{ Sample } & \multirow{2}{*}{ Total } & \multicolumn{4}{|c|}{ Extracted by } \\
\hline & & water & $\begin{array}{c}0.5 \mathrm{~N} \\
\text { acetic acid }\end{array}$ & $\begin{array}{c}1 \% \\
\text { citric } \quad \text { acid }\end{array}$ & $\begin{array}{l}0.1 \mathrm{~N} \\
\mathrm{H}_{2} \mathrm{SO}_{4}\end{array}$ \\
\hline 1. Sp & 17 & 4 & 2 & 3 & 9 \\
\hline 2. CSp & 43 & 9 & 3 & 7 & 13 \\
\hline 3. LCSp & 72 & 4 & 0.4 & 8 & 15 \\
\hline 4. $\mathrm{CSp}_{\mathrm{p}}$ & 60 & 2 & 0.3 & 5 & 21 \\
\hline 5. $\mathrm{SC}_{\mathrm{p}}$ & 75 & 16 & 6 & 15 & 30 \\
\hline 6. $\mathrm{LCp}$ & 115 & 17 & 3 & 27 & 50 \\
\hline 7. $\mathrm{BCp}$ & 23 & 5 & 3 & 6 & 7 \\
\hline 8. EuSCp $_{p}$ & 35 & 11 & 14 & 9 & 20 \\
\hline
\end{tabular}

phosphorus was extracted by $0.5 \mathrm{~N}$ acetic acid and $1 \%$ citric acid, both in the ratio of 1 to 20 , and the time of extraction being one hour. Phosphorus soluble in diluted mineral acid was determined by extracting for half an hour with $0.1 \mathrm{~N}$ sulphuric acid in the ratio of 1 to 100 . The results in Table 2 are reported on the volume basis in order to get figures which are more illustrative than those expressed on the weight basis.

The total content of inorganic phosphorus is fairly low: it varies from $17 \mathrm{mg} / 1$ in sample 1 . Sp to $115 \mathrm{mg} / 1$ in sample 6 . LCp. More than 20 per cent of inorganic phosphorus in samples $1,2,5,7$, and 8 has been extracted by three successive treatments with distilled water. The highest amounts of water soluble phosphorus may be found in the samples 6. LCp and 5. SCp, also the samples 8. EuSCp and 2. CSp are not quite poor in this kind of phosphorus. Figures found for acetic acid soluble phosphorus are markedly lower than those for the water extracts, except in the sample 8. EuSCp which is fairly rich in lime and less acid than the other ones. Also citric acid and sulphuric acid have dissolved the largest amounts of phosphorus from the samples 5. SCp and 6. LCp. Inorganic phosphorus in samples 3. LCSp and 4. CSp seems to be very difficultly soluble in water and weak acids. Since the total content of inorganic phosphorus is extremely low in samples 1 . Sp and 7. BCp, only rather low amounts can be extracted from them in spite of the fact that their inorganic phosphorus appears to be fairly well soluble in water and weak acids.

Its well known that the amounts of inorganic phosphorus extracted by any diluted acid from the soil sample do not generally give any reliable idea of the amount of plant-available phosphorus in the soil. This is particularly true when acid soils are in question. Recently, the fact has been emphasized that the phosphorus condition of a soil depends both on the capacity and the intensity factors. As to the acid soils TERÄSVUORI (6) has tried to dissolve this problem by the determination of the amount of mexchangeable phosphorus" in soil which represents the capacity factor and the corresponding phosphorus concentration in soil solution which represents the intensity factor. The former characteristic is obtained by using an alkali extracting solution $0.1 \mathrm{~N}$ with respect to $\mathrm{KOH}$ and $\mathrm{K}_{2} \mathrm{CO}_{3}$, and the latter one is calculated according to Freundlich's adsorption equation on the basis of 
data for retention of phosphorus from solutions at two different phosphorus concentrations. According to TERÄSVUORI the coefficient in the equation is an indicator of the phosphorus fixing capacity of the soil.

Although this method is not quite satisfactory it was found to be of some help in the characterization of phosphorus condition in mineral soils and in cultivated peat soils. It was applied also to the study of the present soil samples. However, some difficulties arised. It was found that under the conditions of the fixation treatment (heating on a water bath for two hours in two consecutive days) samples 5. SCp, 7. BCp and 8. EuSCp did not adsorb any phosphate from the solution of the lower concentration. Thus, only the amount of exchangeable phosphorus can be reported for these samples. Following results were obtained:

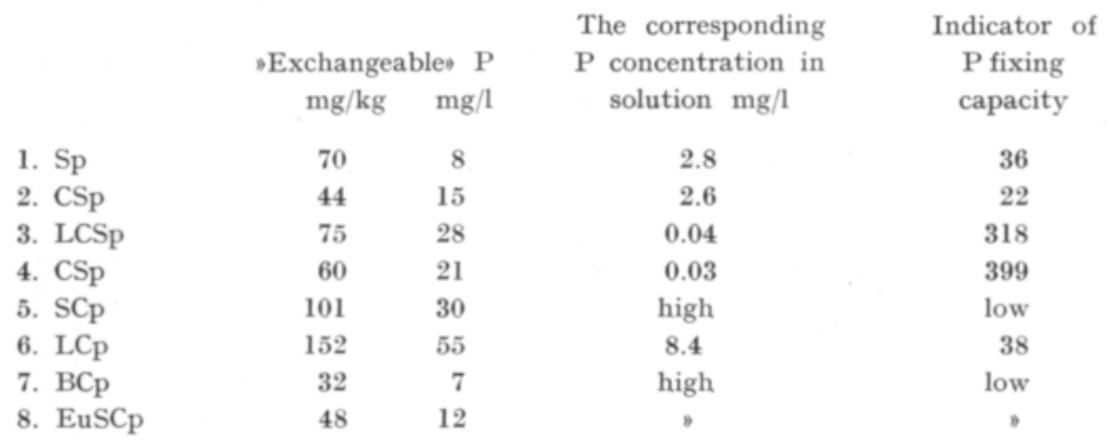

According to these data sample 5. SCp probably supply plants with phosphorus better than the other peats: it has a fairly high amount of mexchangeable" phosphorus and owing to its low fixing capacity also the phosphorus concentration in soil solution" must be high. Good phosphorus conditions exist also in sample 6. LCp which contains even a higher amount of mexchangeable phosphorus" than sample 5. Samples 3. LCSp and 4. CSp, on the other hand, fix phosphorus very intensively and although their capacity factor is not very low, their intensity factor is extremely unsatisfactory. The fairly low amounts of mexchangeable phosphorus» in samples 1 , 2,7 , and 8 will probably be exhausted within a fairly short period.

When results of these chemical analyses are examined the fact must be remembered that the samples were air-dried. This means that under natural conditions the solubility and retention of phosphorus may even considerably differ from the data reported above. When peat soils are in question dried samples generally fix phosphorus more intensively than do the corresponding fresh ones (cf. 4). It means that under natural conditions phosphorus may be more available than it is in the dry samples.

\section{Mobilization of organic phosphorus}

In several papers the possible importance of soil organic phosphorus as a slowly mobilizing phosphorus source has been emphasized. Yet, very little definite facts are available concerning the rate of mineralization of soil organic phosphorus under 
Table 3. Changes in the content of inorganic and organic phosphorus in peat samples incubated for four months at $27^{\circ} \mathrm{C}$

\begin{tabular}{|c|c|c|c|c|c|c|}
\hline \multirow{2}{*}{ Sample } & \multicolumn{3}{|c|}{ Inorganic $\mathrm{P} \mathrm{mg} / \mathrm{l}$} & \multicolumn{3}{|c|}{ Organic $\mathrm{P}$ mg/l } \\
\hline & original & incubated & increase & original & incubated & decrease \\
\hline 1. $\mathrm{Sp}$ & $16 \pm 0.7$ & $19 \pm 1.3$ & $3^{* *}$ & $44 \pm 1.8$ & $38 \pm 1.1$ & $6 * * *$ \\
\hline 2. CSp & $43 \pm 2.2$ & $65 \pm 4.0$ & $22 * * *$ & $175 \pm 2.4$ & $154 \pm 7.5$ & $21 * * *$ \\
\hline 3. $\operatorname{LCSp}$ & $71 \pm 4.6$ & $82 \pm 3.2$ & $11^{*}$ & $302 \pm 6.7$ & $281 \pm 2.3$ & $21 * * *$ \\
\hline 4. $\mathrm{CSp}$ & $63 \pm 2.3$ & $62 \pm 4.0$ & -1 & $306 \pm 9.4$ & $292 \pm 2.1$ & $14^{*}$ \\
\hline 5. $\mathrm{SCp}_{\mathrm{p}}$ & $73 \pm 2.9$ & $89 \pm 0.9$ & $16 * * *$ & $171 \pm 4.7$ & $155 \pm 1.2$ & $16^{* * *}$ \\
\hline 6. $\mathrm{LC}_{\mathrm{p}}$ & $116 \pm 2.6$ & $157 \pm 5.7$ & $41^{* * *}$ & $288 \pm 3.7$ & $245 \pm 6.8$ & $43^{* * *}$ \\
\hline 7. $\mathrm{BCp}$ & $23 \pm 1.4$ & $35 \pm 1.3$ & $12^{* * *}$ & $63 \pm 3.2$ & $50 \pm 1.0$ & $13^{* * *}$ \\
\hline 8. $\operatorname{EuSC}_{\mathrm{p}}$ & $35 \pm 1.3$ & $46 \pm 6.2$ & $11^{*}$ & $124 \pm 5.9$ & $112 \pm 4.5$ & $12^{*}$ \\
\hline
\end{tabular}

natural conditions. As to the peat phosphorus, our informations are particularly scarce. Recently McCALL et al. (5) claimed that in incubation experiments organic phosphorus in peat samples mineralized very rapidly, in some cases almost completely within an incubation period of four months at $27^{\circ} \mathrm{C}$. As far as the author knows this kind of results are exceptional.

In the present study the peat samples were incubated for four months at $27^{\circ} \mathrm{C}$. They were in four replicates, each of them of $1 \mathrm{~g}$. In the water used for moistening calcium nitrate and potassium sulphate were applied, both of them in amounts of $500 \mathrm{mg} / \mathrm{kg}$ of soil. The incubated samples were analyzed for inorganic and organic phosphorus by the acid-alkali method (3). The results in Table 3 are reported on the volume basis.

Some mineralization of organic phosphorus has occurred in most of the samples. It has been highest in the sample 6. LCp in which about 15 per cent of organic phosphorus has turned over into inorganic form increasing this fraction with more than $40 \mathrm{mg} / \mathrm{l}$. In the sample $7 . \mathrm{BCp}$ an even higher percentic mineralization may be detected, about 20 per cent of the organic phosphorus, but it corresponds only to $12-13 \mathrm{mg} / 1$ of phosphorus. A fairly marked mineralization has also occurred in samples 2. CSp and 5. SCp; lower and statistically less significant figures may be found for the samples 3. LCSp and 8. EuSCp. In most of the samples about 5 to 15 per cent of the organic phosphorus has turned over into inorganic forms.

Provided that the mineralization of organic phosphorus would occur under natural conditions and in pot cultures at the same rate as in this incubation experiment, it probably may contribute to the phosphorus nutrition of plants at least in samples 6. LCp and 2. CSp, possibly also in sample 5. SCp. In no one of the samples, however, the mineralization was of that order of magnitude reported by McCALL et al. (5).

\section{Pot experiment}

The availability of peat phosphorus to plants was tested in a pot experiment in which oats were grown in three consecutive years with these peat samples as the only source of phosphorus. 
One liter of air dry and ground peat was well mixed with four liters of washed quarts sand and put into Mitscherlich-pots. All the eight peat samples were treated in four replications.

Each year $0.25 \mathrm{~g}$ of $40 \%$ potash fertilizer and $0.2 \mathrm{~g}$ of ammonium sulphate were applied per pot. In the first year also magnesium sulphate and copper sulphate were applied in amounts of $0.2 \mathrm{~g} /$ pot and $0.025 \mathrm{~g} /$ pot, respectively. In the first two years $2 \mathrm{~g} /$ pot of calcium carbonate was mixed with the peat and sand.

In the beginning of June 50 seeds of "Kultasade IIn-oats were sown to each pot. Later on the sprouts were thinned to 35 plants per pot. The ripen plants were harvested in the end of August or in the beginning of September. Both the seeds and straw were analyzed for total phosphorus by wet digestion and the molybdenum blue method. The peat and sand mixture was then sieved in order to remove roots, and it was stored in pots until the next spring.

The results of the first years are reported in Table 4. On the basis of the grain yields the peat samples may be divided into two groups. In addition to the samples

Table 4. Yield and phosphorus content of the first oat crop

\begin{tabular}{lccccc}
\hline Sample & $\begin{array}{c}\text { Grain } \\
\text { yield } \\
\mathrm{g} / \text { pot }\end{array}$ & $\begin{array}{c}\mathrm{P} \\
\text { in grain } \\
\mathrm{mg} / \mathrm{g}\end{array}$ & $\begin{array}{c}\text { Straw } \\
\text { yield } \\
\mathrm{g} / \text { pot }\end{array}$ & $\begin{array}{c}\mathrm{P} \\
\text { in straw } \\
\mathrm{mg} / \mathrm{g}\end{array}$ & $\begin{array}{c}\text { Total } \mathrm{P} \\
\text { harvested } \\
\mathrm{mg} / \text { pot }\end{array}$ \\
\hline 1. Sp & 5.8 & 2.22 & 8.5 & 0.16 & 14 \\
2. CSp & 8.0 & 2.01 & 12.9 & 0.17 & 18 \\
3. LCSp & 4.9 & 2.18 & 6.6 & 0.20 & 12 \\
4. CSp & 3.7 & 1.66 & 6.0 & 0.18 & 7 \\
5. SCp & 9.1 & 3.99 & 15.3 & 0.48 & 44 \\
6. LCp & 8.0 & 3.42 & 12.1 & 0.40 & 32 \\
7. BCp & 8.5 & 2.11 & 10.9 & 0.15 & 20 \\
8. EuSCp & 7.9 & 2.32 & 12.7 & 0.17 & 20 \\
\hline L.S.D. 5 $\%$ & 1.8 & 0.38 & 3.4 & 0.14 & 7 \\
\hline
\end{tabular}

Table 5. Yield and phosphorus content of the third oat crop

\begin{tabular}{lccccc}
\hline Sample & $\begin{array}{c}\text { Grain } \\
\text { yield } \\
\text { g/pot }\end{array}$ & $\begin{array}{c}\text { P } \\
\text { in grain } \\
\mathrm{mg} / \mathrm{g}\end{array}$ & $\begin{array}{c}\text { Straw } \\
\text { yield } \\
\mathrm{g} / \text { pot }\end{array}$ & $\begin{array}{c}\mathrm{P} \\
\text { in straw } \\
\mathrm{mg} / \mathrm{g}\end{array}$ & $\begin{array}{c}\text { Total P } \\
\text { harvested } \\
\mathrm{mg} / \text { pot }\end{array}$ \\
\hline 1. Sp & 1.5 & 1.70 & 3.3 & 0.19 & 3 \\
2. CSp & 2.1 & 2.00 & 3.8 & 0.23 & 5 \\
3. LCSp & 2.9 & 2.20 & 4.4 & 0.36 & 7 \\
4. CSp & 3.8 & 2.36 & 5.8 & 0.23 & 10 \\
5. SCp & 6.3 & 2.13 & 6.3 & 0.14 & 14 \\
6. LCp & 6.9 & 2.11 & 6.0 & 0.14 & 15 \\
7. BCp & 0.7 & 1.74 & 3.0 & 0.23 & 2 \\
8. EuSCp & 2.5 & 1.84 & 4.1 & 0.14 & 5 \\
\hline L.S.D. 5 \% & 2.0 & 0.37 & 1.5 & 0.13 & 3 \\
\hline
\end{tabular}


5. $\mathrm{SCp}, 6 . \mathrm{LCp}, 7 . \mathrm{BC}_{\mathrm{p}}$ and 8 . EuSCp which originated from tillable peat lands, also the sample 2. CSp from a poor Sphagnum papillosum bog belongs to the better group. Also in regard to the straw yields this grouping is possible, although the differences between the borderline cases are less distinct.

The phosphorus content of the grains is fairly low except in the crop produced by the samples 5. SCp and 6. LCp. In these pots also straw contains more phosphorus than in the other ones. The extremely low phosphorus content of straw indicates that plants have had difficulties in supplying the seeds with enough phosphorus.

The total amounts of phosphorus harvested in the first year varies from $7 \mathrm{mg} / \mathrm{pot}$ from sample 4. CSp to $44 \mathrm{mg} /$ pot from sample 5. SCp. Plants have been able to take up a fairly high amount of phosphorus also from the sample 6. LCp. Owing to the very low phosphorus content of the plants grown on peat 2 . CSp, the total amount of phosphorus harvested from these pots is relatively low although the grain yield and straw yield were equal to those produced by the best peats or samples 5 and 6 .

In the second year the sprouting and the development of the plants were irregular and also the ripening occurred unevenly. In the third year again, the development was normal. The results obtained in this last year are reported in Table 5 .

The yield of the third harvest is low in each pot. Particularly poor growth and scarce uptake of phosphorus are to be found for samples 1 . Sp and 7. BCp, also for samples 2. CSp and 8. EuSCp. Sample 4. CSp which in the first year gave the poorest yield has been able to maintain its former level. Thus it is now third in order after the samples 5. SCp and 6. LCp. In the third crops produced by these two peats not only the total yield but particularly the phosphorus content of both grain and straw is markedly lower than it was in the first crops.

It is not easy to estimate how much peat phosphorus has really been removed by the crops. The 35 seeds left to grow in each pot contained about $3.4 \mathrm{mg}$ of phosphorus. It is likely that during the germination some part of the phosphorus of the 15 seeds later removed was adsorbed by the soil. On the other hand, the roots were sieved away and in them some phosphorus. Owing to the marked differences in the capacity of these samples to fix phosphate the conditions varied between the samples. In lack of any reliable basis it is supposed that in the harvested yield $3 \mathrm{mg}$ of phosphorus in each pot originated from the seed oats. If this is true, the following amounts of phosphorus expressed as $\mathrm{mg} /$ pot or $\mathrm{mg} / \mathrm{l}$ of peat were taken up by the crops from the peat phosphorus:

$\begin{array}{lrccc}\text { Sample } & \text { First year } & \text { Second year } & \text { Third year } & \text { Total } \\ \text { 1. Sp } & 11 & 0 & 0 & 11 \\ \text { 2. CSp } & 15 & 0 & 2 & 17 \\ \text { 3. LCSp } & 9 & 0 & 4 & 13 \\ \text { 4. CSp } & 4 & 0 & 7 & 11 \\ \text { 5. SCp } & 41 & 8 & 11 & 60 \\ \text { 6. LCp } & 29 & 9 & 12 & 50 \\ \text { 7. BCp } & 17 & 0 & 0 & 17 \\ \text { 8. EuSCp } & 17 & 0 & 2 & 19\end{array}$


These figures indicate that in most of the samples the available phosphorus has been exhausted already by the first crop. Only the samples 5. SCp and 6. LCp have continuously been able to supply phosphorus, although even in them a marked drop may be found between tha data for the uptake of the first crop and that of the following ones.

The amounts of phosphorus taken up by the oat crops under the favourable conditions of the pot experiment varied from $11 \mathrm{mg} / \mathrm{l}$ to $60 \mathrm{mg} / \mathrm{l}$ or from about $20 \mathrm{~kg} / \mathrm{ha}$ to $120 \mathrm{~kg} / \mathrm{ha}$. In most of the samples this only corresponds to the need of one or two crops. Under the natural conditions plants in these soils are likely to suffer from the lack of available phosphorus already in the first year. Under cultivation the samples 5. SCp and 6. LCp probably represent peat lands which after reclamation may be cultivated without phosphate fertilizers for one year, at least.

\section{Discussion}

According to the data reported above the eight peat samples of this study appear to represent three different types. There are samples 5. SCp and 6. LCp which contain a relatively high amount of inorganic phosphorus which is fairly easily available. Also the samples 3. LCSp and 4. CSp have a high content of inorganic phosphorus but this is very strongly fixed and plants suffer from the lack of available phosphorus. Samples 1. Sp and 7. BCp are peats with a low phosphorus content and a low fixing capacity. Sample 8. EuSCp belongs to the last group, although it is somewhat richer in phosphorus than the other ones, and its fairly high $\mathrm{pH}$ and calcium content distinguish it from the other ones. Sample 2. CSp with its medium content and availability of phosphorus probably takes an intermediate place between the groups.

Owing to the fact that these eight peat samples represent different types of phosphorus conditions, no single chemical test performed could characterize them all. The capacity and intensity factors determined according to the method of TERÄSVUORI gave together a fairly reliable picture of the mutual order of the samples. The amount of phosphorus taken up by the plants were in some samples higher, in the other ones lower than the amount of mexchangeable phosphorus». Also the amounts of inorganic phosphorus in three successive water extracts, although lower than the quantities taken up by the plants were correlated with them: the correlation coefficient was $0.9^{* *}$. The citric acid value and the uptake of phosphorus were also correlated, but the coefficient was only 0.7 .* $^{*}$

The total content of inorganic phosphorus in these samples was more or less higher than the quantity taken up by the three crops. Thus no conclusion can be drawn of the importance of the mineralization of organic phosphorus. In the incubation experiment the mobilization was in some samples quite marked, and probably it was not negligible in the samples in the pot experiment. This is a problem which needs further study.

It must be emphasized that there are no grounds to connect the phosphorus conditions or the types found in this study with the kind of peat. These samples 
are not likely to be very typical representatives of their kind of peat, and also the material is far too scarce for any reliable conclusions. In addition to this, it is qu ite probable that the amount of inorganic phosphorus and its availability in peat depend more on the degree of humification and the depth of the layer, and also on the sesquioxide content of the soil than on the kind of the peat.

\section{$S u m m a r y$}

The availability to plants of native peat phosphorus was studied by chemical methods and by a pot experiment in which three successive oat crops were grown with peat as the only source of phosphorus. The eight samples were collected from virgin peat lands. They were air-dried and ground.

The samples were found to represent three different types of phosphorus condition: the first group contained relatively high amounts of inorganic phosphorus which was fairly easily available; the second group had a very high capacity to fix phosphorus which made its high quantity of inorganic phosphorus difficultly available; the third group was very poor in total and inorganic phosphorus but the latter was easily soluble and available to plants.

On the basis of the capacity and intensity factors determined according to the method by Teräsvuori and also on the basis of inorganic phosphorus extractable by water fairly reliable predictions could be made of the mutual order of the samples as phosphorus supplyer to the plants in the pot experiment.

In an incubation experiment at $27^{\circ} \mathrm{C}$ the amounts of organic phosphorus mineralized during the period of four months were in some of the samples quite marked, even $40 \mathrm{mg} / \mathrm{l}$, and in most of the samples they corresponded to 5 to 15 per cent of the organic phosphorus.

The amounts of phosphorus taken up by the oat crops under the favourable conditions of the pot experiment varied from 11 to $60 \mathrm{mg} / 1$ or from $20 \mathrm{t} 120 \mathrm{~kg} / \mathrm{ha}$.

\section{REFERENCES}

(1) Kalla, A. 1956. Phosphorus in virgin peat soils. J. Sci. Agr. Soc. Finland 28: 142-167.

(2) — \& KIVEKÄs, J. 1956. Distribution of extractable calcium, magnesium, potassium, and sodium in various depths of some virgin peat soils. Ibid. 28: 237-247.

(3) $\longrightarrow \&$ Virtanen, O. 1955. Determination of organic phosphorus in samples of peat soils. Ibid. 27: $104-115$.

(4) KrVEKäs, J. 1958. Turvenäytteiden kuivaamisen ja jauhamisen vaikutuksesta analyysituloksiin. Summary: The effect of drying and grinding of peat samples on the results of analyses. Ibid. 30: $1-9$.

(5) McCall, W. W., Davis, J. F. \& Lawton, K. 1956. A study of the effect of mineral phosphates upon the organic phosphorus content of organic soil. Soil Sci. Soc. Amer. Proc. 20: 81-83.

(6) TERÄsvuori, A. 1954. Uber die Anwendung saurer Extraktionslösungen zur Bestimmung des Phosphordüngerbedarfs des Bodens, nebst theoretischen Erörterungen über den Phosphorzustand des Bodens. Publ. Staatl. Landw. Versuchsw. Finnland Nr 141. Helsinki, 64 p. 


\section{SELOSTUS:}

\section{TURPEESTA KASVIEN FOSFORIN LÄHTEENÄ}

\section{Armi KaILA}

\section{Yliopiston maanviljelyskemian laitos, Helsinki}

Tutkimuksessa on yritetty selvittää kemiallisin menetelmin ja kolmivuotisella astiakokeella turpeen fosforin käyttökelpoisuutta. Tutkimusaineistona oli kahdeksan luonnontilaisilta soilta kerättyä näytettä, jotka kuivattiin ja jauhettiin ennen analyysejä ja astiakoetta.

Turpeiden todettiin edustavan kolmea eri tyyppiä. Ensimmäisen ryhmän näytteissä oli melko runsaasti epäorgaanista fosforia, joka oli verraten helposti liukenevaa ja kasvien otettavissa. Toisen ryhmän näytteet pidättivät fosforia erittäin lujasti, ja huolimatta suurehkosta kokonaismäärästä käyttökelpoista fosforia oli hyvin niukasti. Kolmannen ryhmän näytteiden pieni fosforimäärä oli helposti liukenevaa ja kasvien saatavissa.

Teräsvuoren vaihtuvaa fosforia ja vastaavaa liuoksen fosforin väkevyyttä edustavat arvot sekä toisaalta myös kolmessa peräkkäisessä uutossa veteen liukeneva fosfori kuvastivat melko selvästi näytteiden keskinäistä suhdetta kauran fosforinlähteenä astiakokeessa.

Muhituskokeessa $\left(4 \mathrm{kk}, 27^{\circ} \mathrm{C}\right)$ mineraloitui joistakin näytteistä melkoisesti fosforia, jopa $40 \mathrm{mg} / \mathrm{l}$. Useimmissa mineraloitunut määrä oli $5-15 \%$ orgaanisen fosforin kokonaismäărästä.

Kaura otti astiakokeiden suotuisissa olosuhteissa eri näytteistä fosforia yhteensä $11-60 \mathrm{mg} / \mathrm{leli}$ $20-120 \mathrm{~kg} / \mathrm{ha}$. 